\title{
Sandra Walklate and Gabe Mythen, Contradictions of Terrorism: Security, Risk and Resilience. London and New York: Routledge 2014.
}

194 pp., US \$ 44.95 [Paperback]; ISBN 978-0-415-62653-8.

\section{reviewed by Nick J. Sciullo}

\section{(cc) $\mathrm{BY}$}

This work is licensed under a Creative Commons Attribution 3.0 License.

\begin{abstract}
S andra Walklate and Gabe Mythen have written a strong contribution to critical terrorism studies as part of Routledge's New Directions in Critical Criminology series. The series, which has tackled drug policy, globalization, and rural criminology, among other topics, is characterized by short, academically rich texts from leading authors in their respective fields. Walklate and Mythen do not disappoint as both are veterans of critical terrorism studies and superb writers.

This book is recommended for graduate students, faculty in need of a short compendium on recent literature and potential new directions in the field, and practitioners who look to combine theory and practice in their work. While not without fault, some structural and some argumentative, this book deserves a place in research libraries and bookshelves for its strong prose, succinct martialing of evidence, and interdisciplinary approach.
\end{abstract}

Before addressing the missteps in this book, it is important to get a sense of its structure. For those interested in longer books and more complete arguments, readers should look to Mythen's Understanding the Risk Society: Crime, Security and Justice, which will expose readers to more nuances and a deeper theoretical understanding of Mythen's risk society. The book under review contains an introduction, six chapters, and a conclusion, with a helpful index. As the chapter titles indicate, the authors are guided by not simply critical terrorism studies, but also critical and sociological theory. Readers familiar with the work of Slavoj Žižek, Mitchell Dean, Pierre Bourdieu, Noam Chomsky, and Alain Badiou are likely to find this work a fast-paced introduction to the ways critical theory can be applied to the study of terrorism. Those researchers of a more traditional bent will be rewarded as well as Walklate and Mythen aptly cover the work of Richard Jackson, Zygmunt Bauman, and Samuel Huntington, all more familiar names for international relations scholars.

One way to judge a book is to by its adherence to the promise of its introduction. Walklate and Mythen write, "In the conclusion to the book, we endeavour to consciously muddy these particular conceptual waters and create some space for differently nuanced understandings to emerge within criminology. If we fail to create and protect an alternative discursive space, our quest to understand terrorism will remain as elusive as ever" (p. 13). Noble goals, to be sure, but they are only partially fulfilled. This book does open up space to engage terrorism by continuing the critical terrorism studies discussion, but it does not create new space. This is a difficult idea with which to grapple because in an otherwise find book, there is not much new work done, which is why it represents a great text for graduate students, but only a great review of work for established scholars.

One problem with this text though is that it reproduces much existing work. In fact, the authors cite so frequently to their own work in other forums, that the reader begins to wonder if an edited collection of 


\section{Journal of Terrorism Research}

those works might be a more worthwhile project with a thoughtful introductory essay. That is not to say that the combinations of critical theorists, political scientists, and international relations scholars are not interesting or informative, but that this is well-walked territory, often by the authors themselves. So readers may better understand terrorism, but not understand terrorism in new ways. For these reasons the authors are only partially successful on their terms they lay out for evaluating their project.

Argumentatively, the authors conclude that "the issues debated in this book are of crucial concern for a discipline that aspires to be politically relevant and socially present" (p. 186). True enough, but the authors have not made a case that critical criminology and certainly traditional criminology are not politically relevant and socially present. It seems quite the opposite-both are politically relevant and socially present in issues of mass incarceration, sentencing, prison abolition, drug policies, and legal reforms.

Lastly, the authors seem to have left some bodies of literature out of this short volume. Perhaps that is a function of the book's length, but even so there are some glaring omissions. Surprisingly, Jacques Derrida, Alberto Toscano, and Carol Winkler's are all left out despite their relevance for the task at hand.

Overall, this book is a good read and brings together much literature perhaps unfamiliar for criminologists. While seasoned critical terrorism scholars may wish there was more here; the book is rewarding in many respects and in such a small volume the authors should be commended for accomplishing what they did.

\section{About the reviewer: Nick J. Sciullo is Assistant Professor of Communication and Rhetorical Studies and} Director of Debate and Forensics at Illinois College (beginning July 2015). He expects to receive his Ph.D. in communication from Georgia State University in Atlanta, Georgia, USA this summer. He has written on critical terrorism studies and law in the Willamette Law Review, Drexel Law Review, and British Journal of American Legal Studies. 